\section{Inheritance of Resistance to Passionfruit Woodiness Virus in Common Bean (Phaseolus vulgaris L.)}

\author{
R. Provvidenti ${ }^{1}$ \\ Experiment Station, Geneva, NY 14456-0462 \\ Additional index words. Passiflora sp., peas, viruses, resistance, genetics
}

Cornell University, Department of Plant Pathology, New York State Agricultural

\begin{abstract}
Passionfruit woodiness virus (PWV) can infect bean (Phaseolus vulgaris L.), causing a light and dark green foliar mosaic, veinbanding, downward curling, and plant stunting. The intensity of these symptoms can vary with the strain of the virus and cultivar, but they resemble those caused by bean common mosaic virus. In genetic populations derived from crosses and backcrosses involving cultivars that are resistant ('Black Turtle 1', 'Clipper', and 'RedKote') or susceptible ('Black Turtle 2', 'California Light Red Kidney', and 'Pioneer'), a single dominant gene conferred resistance to an Australian strain PWV-K. To this gene, the symbol $P w v$ (Passionfruit woodiness virus) is tentatively assigned. In plants derived from rooted cuttings of backcross populations, the same factor also conditioned resistance to three other Australian strains, PWV-Mild, PWV-51, and PWV-Tip Blight.
\end{abstract}

Passionfruit woodiness virus (PWV) is considered to be one of the major Potyviridae affecting passionfruit (Passiflora edulis Simms.) and related species. It was originally described by McKnight (1953) and has since been found in other tropical and subtropical regions of the world (Provvidenti and Niblett, 1994; Taylor and Greber, 1973). The host range of this virus also involves members of the Leguminosae, including the common bean (Phaseolus vulgaris L.) Taylor and Greber, 1973). Very little is known about the presence of PWV in common bean crops grown in warm areas of the world. However, a few years ago, it was found to occur in the Federal District and Cristalina, Goias State, Brazil, where it caused severe symptoms on local bean cultivars (Inoue et al., 1995). Experimentally, they found that a few cultivars were resistant. In our work on biological properties of PWV from Australia (PWV-K), Puerto Rico (PWV-PR), and Thailand (PWV-T), American common bean cultivars were useful in differentiating these strains. The Australian strain systematically infected more bean lines $(16 / 32)$ than did the other two strains (Provvidenti, 1992), and was one of the few strains capable of infecting pea (Pisum sativum L). However, among the pea lines tested, 23 of 30 were found to be highly resistant. Inheritance studies revealed that in peas, the resistance is conferred by a single recessive gene (Provvidenti and Niblett, 1994) Conversely, our preliminary tests indicated that the resistance to PWV-K in common beans was

Received for publication 17 May 1999. Accepted for publication 20 Sept. 1999. The cost of publishing this paper was defrayed in part by the payment of page charges. Under postal regulations, this paper therefore must be hereby marked advertisement solely to indicate this fact.

${ }^{1}$ E-mail address: rp13@ cornell.edu dominant (Provvidenti, 1993). The data presented herein confirm the dominance of resistance in common beans to PWV-K and three other Australian strains.

\section{Materials and Methods}

A few cultivars reported to be resistant $(\mathrm{R})$ or susceptible (S) to PWV-K (Provvidenti, 1992), were selected for inheritance studies, The following crosses were made: 'Black Turtle 1' (BT-1) (R) x 'Black Turtle 2' (BT-2) (S); 'Redkote' (R) x 'California Light Red Kidney' (CLRK) (S); and 'Clipper' (R) $x$ 'Pioneer' (S). Both BT-1 and BT-2 have black seedcoats and belong to the Andean Group, whereas the Middle American Group includes CLRK and 'Redkote' (red seedcoats) and 'Clipper' and 'Pioneer' (white seedcoats). A culture of the PWV-K strain was available from previous studies (Provvidenti, 1992, 1993; Provvidenti and Niblett, 1994), whereas the Australian PWV-Mild (M), PWV-51, and PWV-Tip Blight (TB) (Shukla et al., 1988), were kindly supplied by Dr. R.S. Greber (Queensland, Australia). Cultures of these strains were maintained in CLRK plants, and inocula were prepared by macerating young infected leaves with a phosphate buffer $(0.05$ $\mathrm{M} \mathrm{K}_{2} \mathrm{HPO}_{4}$ at $\mathrm{pH}$ 8.5. For inheritance studies involving $\mathrm{PWV}-\mathrm{K}$, plants of the parental lines and populations of $F_{1}, F_{2}$, and backcross $F_{1}$ to both parents were mechanically inoculated on the expanded primary leaves and reinoculated a week later on the first trifoliates. This dual inoculation minimized the number of escapes. To confirm infectivity, bean plants were assayed by enzyme-linked immunosorbent assay (ELISA) using an antiserum to PWV previously obtained from Dr. Greber (Provvidenti and Niblett, 1994). When ELISA was inconclusive, recovery tests were made using CLRK as a systemic host. To determine whether the same resistance factor(s) conferred resistance to different Australian strains of PWV, four cuttings were made from each plant of three backcross populations: (BT-1 X BT-2) x BT-2, ('Clipper' X 'Pioneer') x 'Pioneer', and ('Redkote' $x$ CLRK) $x$ CLRK. After rooting, the resulting plants were inoculated individually with one of the four strains (TWV-K, -M, -51, or -TB). All of the plants were grown in sterilized clay pots $(500-\mathrm{mL}$ volume) containing the Cornell artificial mix (sphagnum peatmoss, Whittemore vermiculite, Baker's dolomitic limestone, and $\mathrm{CaNo}_{3}$. Every week, plants were fertilized with the water-soluble 'Start-N-Gro' (14N-28P-14K) (Agway, Syracuse, N.Y.), and treated with ENSTAR II $\{$ S-Kinoprene [2-propynyl (2E,4E)-(7S)-3,7,11-trimethyl-2-4-dodecadienoate]\} (Sandoz Agro, Des Plaines, Ill.) This insecticide was used for the control of whiteflies, aphids, armored scales and mealybugs, and kept plants completely free of viral vectors. During the winter months, natural light was supplemented with fluorescent lights for $16 \mathrm{~h}$ daily. Plants were kept in a greenhouse, where temperature ranged from 25 to $30^{\circ} \mathrm{C}$, with a relative humidity $(\mathrm{RH})$ of $40 \%$ to $60 \%$.

\section{Results and Discussion}

Plants of BT-1 and 'Redkote' remained free of local and systemic symptoms after two inoculations with PWV-K, but 'Clipper' developed small necrotic lesions confined to the inoculated primary leaves. ELISA confirmed that the virus had infected inoculated leaves of plants of these three cultivars, but had failed to move systemically (systemic resistance). The virus infected locally and systemically plants of BT-2, CLRK, and 'Pioneer'. Initially, necrotic local lesions were visible only on primary leaves of 'Pioneer', but eventually, veinal browning and interveinal chlorosis also developed on those of BT-2 and CLRK. Systemic symptoms initially consisted of a light and dark green mottle, followed by a prominent mosaic, green veinbanding, downward leaf curling, and plant stunting. The $\mathrm{F}_{1}$ plants of the crosses BT- $1 \mathrm{x}$ BT-2, 'Clipper' $x$ 'Pioneer', and 'Redkote' $x$ CLRK responded to inoculation with local infection, but, as in the resistant parents, the virus failed to move systemically. The $F_{2}$ plants of these crosses segregated in a ratio of 3 systemically resistant : 1 susceptible. Systemically infected plants exhibited the same type of symptoms displayed by those of the susceptible parents. Backcross populations involving the susceptible parents (BT-1 $\mathrm{X}$ BT-2) x BT-2, ('Clipper' $x$ 'Pioneer') $x$ 'Pioneer'), and ('Redkote' $x$ CLRK) $x$ CLRK segregated in a ratio of $\approx 1$ systemically resistant : 1 susceptible. The backcross populations involving resistant parents (BT-1 $\times$ BT2) X BT-1, ('Clipper' X 'Pioneer') X 'Clipper', and ('Redkote' $x$ CLRK) $x$ 'Redkote', were all systemically resistant. Thus, based upon the data presented in Table 1, the resistance to PWV-K in BT-1, 'Clipper', and 'Redkote' is conferred by a single dominant factor. There- 
Table 1. Inheritance of resistance in common bean (Phaseolus vulgaris L.) to an Australian strain of passionfruit woodiness virus (PWV-K).

\begin{tabular}{|c|c|c|c|c|c|}
\hline \multirow[b]{2}{*}{ Parents and cross progeny } & \multicolumn{2}{|c|}{ No. of plants } & \multirow{2}{*}{$\begin{array}{c}\text { Expected ratio } \\
(\mathrm{R}: \mathrm{S})\end{array}$} & \multirow[b]{2}{*}{$\chi^{2}$} & \multirow{2}{*}{$\begin{array}{c}\text { Goodness of fit } \\
(P)\end{array}$} \\
\hline & Resistant & Susceptible & & & \\
\hline Black Turtle 1 (BT-1) & 54 & 0 & & & \\
\hline Black Turtle $2(\mathrm{BT}-2)^{\mathrm{y}}$ & 0 & 51 & & & \\
\hline Clipper $^{1}$ & 43 & 0 & & & \\
\hline Pioneer $^{2}$ & 0 & 37 & & & \\
\hline Redkote $^{1}$ & 35 & 0 & & & \\
\hline \multirow[t]{2}{*}{ CA Light Red Kidney (CLRK) } & 0 & 48 & & & \\
\hline & & $B T-1 \times B T-2$ & & & \\
\hline $\mathrm{F}_{1}$ & 35 & 0 & & & \\
\hline $\mathrm{F}_{2}$ & 84 & 24 & $3: 1$ & 0.444 & 0.51 \\
\hline $\mathrm{BC}\left(\mathrm{F}_{1} \times \mathrm{BT}-2\right)$ & 42 & 0 & & & \\
\hline \multirow[t]{2}{*}{$\mathrm{BC}\left(\mathrm{F}_{1} \times \mathrm{BT}-2\right)$} & 35 & 31 & $1: 1$ & 0.242 & 0.64 \\
\hline & & Clipper $x$ Pione & & & \\
\hline $\mathrm{F}_{1}$ & 47 & 0 & & & \\
\hline $\mathrm{F}_{2}$ & 97 & 29 & $3: 1$ & 0.264 & 0.62 \\
\hline $\mathrm{BC}\left(\mathrm{F}_{1} \times\right.$ Clipper $)$ & 77 & 0 & & & \\
\hline \multirow[t]{2}{*}{$\mathrm{BC}\left(\mathrm{F}_{1} \times\right.$ Pioneer $)$} & 43 & 38 & $1: 1$ & 0.604 & 0.48 \\
\hline & & Redkote $\times$ CLR & & & \\
\hline $\mathrm{F}_{1}$ & 28 & 0 & & & \\
\hline $\mathrm{F}_{2}$ & 76 & 22 & $3: 1$ & 0.264 & 0.57 \\
\hline $\mathrm{BC}\left(\mathrm{F}_{1} \times\right.$ Redkote $)$ & 39 & 0 & & & \\
\hline $\mathrm{BC}\left(\mathrm{F}_{1} \times \mathrm{CLRK}\right)$ & 27 & 24 & $1: 1$ & 0.176 & 0.68 \\
\hline
\end{tabular}

${ }^{\mathrm{y}}$ Susceptible.

fore, the symbol Pwv (Passionfruit woodiness virus) is tentatively assigned to this gene. Considering that this factor is present in beans belonging to both the Andean and the Middle American groups of P. vulgaris, it can be transferred by regular breeding into susceptible cultivars of each group.

To determine whether the same dominant gene was able to confer resistance to four distinct strains of PWV, four rooted cuttings of each plant of the three backcross populations were inoculated individually with strains PWV-K, -M, -51, or -TB. Plants of each set segregated in a ratio of $\approx 1$ systemically resistant : 1 susceptible within each strain of the virus; 1$)$ the progeny of (BT-1 x BT-2) $\mathrm{X}$ BT-2 included 35 resistant and 31 susceptible $(P=0.64)$; 2) 'Clipper' $\mathrm{X}$ 'Pioneer') $\mathrm{x}$ 'Pioneer' comprised 43 resistant and 38 susceptible $(P=0.45)$; and 3) ('Redkote' $\mathrm{x}$ CLRK ) $x$ CLRK contained 27 resistant and 24 susceptible plants $(P=0.68)$. These results agree with the presence of a single gene conferring resistance to four different Australian strains of PWV.

In common beans, the type of symptoms incited by the four Australian strains of PWV were essentially similar, but they ranged from mild (PWV-M), to moderate (PWV-51), to prominent (PWV-K), to severe (PWV-TB). The prominence of symptoms on susceptible genotypes incited by PWV-K helped in analyzing genetic populations during inheritance studies. Gough and Shukla (1992) reported that the coat protein sequence of PWV-K differed in the N-terminus from those of other strains, but serologically they were all related. PWV-K was the only Australian strain able to infect peas (Provvidenti and Niblett, 1994).

Further work is needed to ascertain the distribution of PWV in common bean crops grown in tropical and subtropical regions of the world, where this virus is prevalent in Passiflora sp. Considering that symptoms incited by this virus in common beans resemble those caused by bean common mosaic virus (BCMV), also of common occurrence in warm regions, very few efforts have been made to determine the presence, distribution, and economical importance of PWV. BCMV and PWV are not serologically related and the latter has a wider host range than the former (Taylor and Breber, 1973). Resis- tance to BCMV in common beans can be strain-specific and conditioned by: 1) recessive genes $\left(b c-1, b c-1^{2}, b c-2, b c 2^{2}\right.$, and $\left.b c-3\right)$; 2) a dominant gene (II); and 3 ) a combination of a recessive and the dominant factor (Drijfhout et al., 1978). In 'Clipper', the resistance to BCMV is recessive, and in BT-1 and 'Redkote', it is dominant. Our work has established that in these three cultivars, the resistance to PWV is conferred by a nonstrainspecific dominant factor $(P w v)$. However, a number of common bean cultivars possess resistance to BCMV and PWV (e.g., 'Alliance', BT-1, 'Benton', 'Bonanza Wax', Bounty', 'Bush Blue Lake 47', 'King Horn Wax', 'Labrador', 'Midnight', 'RedKloud', 'RedKote', 'Royal Red', 'Vitagreen', and others) (Provvidenti, 1992).

\section{Literature Cited}

Drijfhout, E., M.J. Silbernagel, and D.W. Burke. 1978. Differentiation of strains of bean common mosaic virus. Neth. J. Plant Patho. 84:13-26.

Gough, K.N. and D.D. Shukla. 1992. Major sequence variation in the $\mathrm{N}$-terminal region of the capsid protein of a severe strain of passionfruit woodiness potyvirus. Arch. Virol. 124:389-396.

Inoue, A.K., R.N. Mello, T. Nagata, and E.W. Kitajima. 1995. Characterization of passionfruit woodiness virus isolates from Brasilia and surrounding region, Brazil. Fitopatologia Brasileria 20:479-487.

McKnight, T. 1953. The woodiness of passion vine (Passiflora edulis Simms.). Queensland J. Agr. Sci. 10:4-35.

Provvidenti, R. 1992. Passionfruit woodiness virus infectivity in Phaseolus vulgaris and sources of resistance. Bean Improvement Coop. Annu. Rpt. 35:144-1445.

Provvidenti, R. 1993. Resistance to three strains of passionfruit woodiness virus in Phaseolus vulgaris. Bean Improvement Coop. Annu. Rpt. 36:137-138.

Provvidenti, R. and C.L. Niblett. 1994. Inheritance of resistance to a strain of passionfruit woodiness virus in pea (Pisum sativum L.) HortScience 29:901-902.

Shukla, D.D., M.N. McKern, and C.W. Ward. 1988. Coat protein of potyviruses. 5. Symptomatology, serology, and coat protein sequences of three strains of passionfruit woodiness virus. Arch. Virol. 102:221-232.

Taylor, R.H. and R.S. Greber. 1973. Passionfruit woodiness virus. In: Description of plant viruses no. 122. Commonwealth Mycological Institute/Association of Applied Biologists, Ferry Lane, Kew, Surrey, United Kingdom. 